\title{
Effect of Carbomer as an Adjuvant for Enhancement of Immune-Response Against FMD Vaccine
}

\author{
Walaa S. Shabana $^{1 *}$ and Abeer Abd EL-Sadek ${ }^{2}$ \\ ${ }^{1}$ Foot and Mouth Disease Research Department, Veterinary Serum and Vaccine Research Institute (VSVRI), \\ Agricultural Research Center (ARC), Abassia, Cairo, Egypt. \\ 2 Department of Infectious Diseases, Faculty of Veterinary Medicine, El-Wadi El-Gadid University, Egypt. \\ "Corresponding Author, Walaa S. Shabana, E-mail: walaa.shabanaomar@gmail.com
}

\begin{abstract}
This work was designed to provide high protective, long-lasting immunity against FMD by enhancing the immunogenicity of the trivalent FMD vaccine using carbomer as adjuvant using G. pigs as an alternative cheapest animal model for quality control testing of the prepared FMD vaccines formulae. Guinea pigs were chosen as experimental models to develop concepts and techniques to study the PD50 of FMD vaccines because of the similarities of clinical symptoms in these animals to those of swine and cattle to saving cost, three different formulae of inactivated trivalent FMD vaccine including serotypes O Pan Asia2, A Iran O5 and SAT2/EGY/2012 were prepared as formula 1- (50\% carbomer to $50 \%$ antigen); formula 2 (50\% Montanide ISA 206 to 50\%antigen) and formula 3- (25\% Montanide ISA 206 and 25\% carbomer with $50 \%$ antigen). All of such formulae were found to be free from foreign contaminants, safe and potent, showing no postvaccinal reactions and high protective levels of specific FMD antibodies in Guinea pigs. Each vaccine formula's immunogenicity was determined by estimation of 50\% Guinea pig protective dose $\left(\mathrm{GPPD}_{50}\right)$ and monitoring of the humeral antibody response of vaccinated G. Pig groups. It was found that Montanide oils 206 with carbomer is the best vaccine formula, followed by Montanide oils 206 and finally carbomer which give early short-lasting immunity.
\end{abstract}

Keywords: Adjuvants, Carbomer, FMD, Montanide ISA206.
Original Article:

DOI:https://dx.doi.org/10.21608/javs.20 21.154578

Received :08 February, 2021.

Accepted :01 March, 2021.

Published in April, 2021.

This is an open access article under the term of the Creative Commons Attribution 4.0 (CCBY) International License . To view a copy of this license, visit:

http://creativecommons.org/licenses/by/4.0/

\section{INTRODUCTION}

Foot and mouth disease (FMD) is one of the most highly contagious diseases of cloven-hoofed animals worldwide (Grubman and Baxt, 2004). FMD is able to infect G. Pigs, buffalo, goats, pigs and wild cloven-hoofed animals. FMD virus (FMDV) is the real causative agent, represented by seven serotypes (A, C, O, SAT1, SAT2, SAT3 and Asia1) (Depa et al., 2012). The main clinical signs in infected animals are fever, vesicular lesions on the tongue, snout, feet and teats, and lameness with high morbidity and low mortality (Satya, 2009). The circulating FMDV serotypes in Egypt are serotypes O, A, and SAT2 (Aidaros, 2002; Abd El-Rahman et al., 2006; Abd El-Aty et al., 2013). Control of FMD using vaccination depending on the factors influencing the vaccine potency and the induction of a protective antibody response is the integrity of the structural protein and the intact virion using 146S (Doel, 2003).

Guinea pigs were chosen as experimental models to develop concepts and techniques to study the PD50 of FMD vaccines because of the similarities of clinical symptoms in these animals to swine and cattle to save cost (Richard et al., 1979 and Eman, 2012). Guinea pigs are susceptible animals to FMD and can be protected by aqueous FMD vaccines. The methods of demonstrating the potency of such vaccines using Guinea pigs have been described as having a good correlation with cattle protection (Black et al., 1985).

Foot and mouth disease vaccine adjuvanted with Montanide ISA oil was found to be valid for more than two years when the $50 \%$ guinea pig protective dose (GPPD50) was calculated (Samira et al., 1999). 


\section{Effect of Carbomer as an Adjuvant for ........}

The quantity of $146 \mathrm{~S}$ particles in inactivated FMD virus vaccine samples produced in FMD Vaccine Production Center in Thailand could be estimated by the sucrose gradient ultracentrifugation and optical density analysis by using the computer applying system (Shiari et al., 1990). Using 146S assay only or some serological tests which together increase the reliance on estimating potency of specific vaccine batch. They can also be assembled with an interconnected method which is based on the $146 \mathrm{~S}$ concentration of the final vaccine batch (Alkan et al., 2008). Adjuvants stimulate the immune response and increase the immunity duration and the adjuvant nature can determine the particular type of immune response (Mair et al., 2015)

The capturing of soluble immune mediators such as cytokines and chemokines could result in exemplary intercellular signaling and into more efficient leukocyte recruitment to the site of vaccine delivery. Alternatively, carbomer action could rely on nonimmune cells, whose role in promoting immunity would be revealed in subsequent time (Mair et al., 2015). Carbomer was previously used in horse vaccines (Mumford et al., 1994 and Minke et al., 2007), pigeons and swine vaccines (Vereecken et al., 2000). The adjuvant criteria of polyacrylic acids, designated by the term carbomers, may vary significantly with the number of carboxyl groups present in the final molecule. Polyacrylic acid polymers termed carbomers have been evaluated as adjuvants in animal vaccines with no side effect (Mair et al., 2015; Mumford et al., 1994; Gualandi et al., 1988; Hoogland et al., 2006; Liu et al., 2005 and Tollersrud et al., 2002).

The use of carbomer as an adjuvant can induce robust humoral immunity and $\mathrm{T}$-cell responses to some subunit vaccines (Mumford et al., 1994). Adding carbomer to animal vaccines results in systemic adjuvant activity, including proinflammatory $\mathrm{T}$ cell sensitization, fast leukocyte recruitment, proinflammatory cytokine secretion with antigen capture fast by the inflammatory monocytes (Gartlan et al., 2016).

It was shown that Carbomer 934 is actually immunogenic and maybe a relevant alternative to oil in avian species for which safety is a major concern). Aluminum hydroxide was proved to be less immunogenic than carbomer and the last was totally safe by vaccination the young goslings with inducing a good serological response (Jacqueline et al., 2011).

In a trial to improve the rabies vaccine's immunogenicity, water-soluble acrylic acid (carbomer) was used as an adjuvant revealing that it is potent and efficient (Naglaa et al., 2020). It was suggested that to yield potentially high immune response made combination to carbomers with other adjuvant formulations such as MF59 (Lai et al., 2012 and Dey et al., 2012). It could be concluded that the Montanide oils 206 with carbopol is the best vaccine formula which induced earlier, long-lasting immunity followed by Montanide oils 206 and finally Carbopol which give early, short-lasting immunity when vaccinated 160 calves (El-Sayed and Salma, 2021).

This work was designed to provide high protective, long-lasting immunity against FMD through the enhancement of the immunogenicity of the trivalent FMD vaccine using carbomer as adjuvant using G. pigs as an alternative cheapest animal model for quality control testing of the prepared FMD vaccines formulae.

\section{MATERIALS AND METHODS}

\section{Guinea pigs}

Two hundred thirty-five (235) healthy adult male Albino Guinea pigs approximately 400-500 gm body weight were used to prepare Guinea pig adapted FMD virus to be used for Guinea pig challenge and for determination of the potency of the prepared vaccines formulae. These animals were supplied by Lab Animal Farm (LAF) in Veterinary Serum and Vaccine Research Institute (VSVRI).

\section{FMD virus strains}

Local FMDV serotypes (A Iran O5, O Pan Asia2 and SAT2/EGY/2012) were inoculated in BHK21 cell culture to prepare virus fluid were supplied by the Department of FMD Vaccine Research (DFMDVR); (VSVRI).

\section{Cell culture}

Baby Hamster kidney cell line (BHK21) was propagated and maintained using Eagle's Minimum Essential Medium (MEM) supplied with 8-10\% newborn calf serum as described by Xuan $\boldsymbol{e t}$ al., (2011) and used for SNT, virus propagation and titration for vaccine preparation.

\section{Guinea pig adapted virus}

Albino Guinea pigs were inoculated by FMD virus strain $\mathrm{O}$ pan Asia-2, A Iran O5 and SAT2 / EGY/2012 intra-dermoplanter in the metatarsal pads. After 24-48 hours, the developed lesions were collected aseptically. The lesion extract was re-inoculated in other Guinea pigs five times until the virus became entirely adapted to Guinea pigs, as recommended by Sonia (2007).

\section{Virus infectivity and antigenicity}

Titration of the used FMD virus serotypes was carried out and the infectivity titer was calculated in $\log _{10} \mathrm{TCID}_{50}$ as described by Reed and Muench (1938). The complement fixation test (CFT) was carried out according to the Health Protection Agency (2009). 


\section{Virus inactivation}

FMDV serotypes (A Iran O5, O Pan Asia2and SAT2/EGY/2012) at their seventh passage on BHK21 cell line with an infectivity titer of $10^{8}$ TCID $_{50} / \mathrm{ml}$ were subjected to inactivation process by a combination of $0.04 \%$ formaldehyde and $1 \mathrm{mM}$ binary ethyleneimine (BEI) as the method described by Barteling and Cassim (2004) and Ismail et al., (2013). To neutralize the effect of BEI $20 \%$ of sodium thiosulfate in a final concentration of $2 \%$ and also to neutralize the excess of formalin $20 \%$ of sodium bisulfite in a final concentration of $2 \%$ were added.

\section{Estimation of antigenic content (Total protein and 146S) in FMD virus serotypes}

Protein estimation of FMD prepared antigen was performed by Bradford's method. The concentration of $146 \mathrm{~S}$ particles in the virus preparation was estimated by using sucrose density gradient ultracentrifugation by determining the absorbance at $254 \mathrm{~nm}$ using ISCO $520 \mathrm{C}$ Density Gradient system as described by Doel and Chong (1982) and Bartelling et al., (1990).

\section{Used adjuvants}

8.1. Carbomere adjuvant was provided by Lubrizol Co. as a fluffy white powder. It was dissolved in hot water to prepare $0.5 \%$ aqueous stock solutions, sterilized by autoclaving at $121^{\circ} \mathrm{C}$ for $20 \mathrm{~min}$, then stored at $4^{\circ} \mathrm{C}$ until further use (United States Pharmacopeial Convention, 1990).

8.2. Montanide ISA206 was supplied from Seppic, Paris, France.

\section{Preparation of inactivated vaccines}

Mixing of the inactivated FMDV serotypes for vaccine preparation was carried out after estimation of virus titer and 146S antigen content from each FMD virus strain.

\section{Formulation of the prepared experimental vaccine batches}

Three formulae of trivalent inactivated FMD vaccine were prepared according to Gamil (2010) and El-Sayed et al. (2012) using the mentioned adjuvants as follow:

- Formula (1) prepared with 50\% carbomer and $50 \%$ antigen

- Formula (2) prepared with 50\% Montanide ISA 206 oil and 50\%antigen

- Formula (3) prepared with $25 \%$ Montanide ISA 206 oil; $25 \%$ carbomer with $50 \%$ antigen.
11. Evaluation of the prepared FMD vaccine formulae

11.1. Physical parameters: Physical parameters of the vaccines like viscosity, stability and emulsion type were studied as described by Stone (1988).

11.2. Sterility testing: Sterility assays of all prepared and FMD vaccine formulae were performed by on thioglycolate broth, Sabouraud's agar; Nutrient agar; phenol dextrose media and mycoplasma medium according to (OIE 2017).

11.3. Safety testing: The safety of each prepared vaccine formulae was tested by subcutaneous inoculation of double dose in the G. Pigs. (OIE 2017)

11.4. Potency test of the prepared FMD trivalent vaccine formulae:

11.4.1. Determination of $50 \%$ Guinea pig's protection dose $\left(\right.$ GPPD $\left._{50}\right)$

It was carried out according to Black et al., (1985), (Assem, 2010) and Challa et al. (2011) where 100 Guinea pigs were divided into four groups $(25 \mathrm{G}$. pigs/ group) as follow:

- The $1^{\text {st }}$ group was vaccinated with FMD inactivated vaccine adjuvanted with carbomer alone using fourfold dilution (undiluted, 1/4, $1 / 16,1 / 64,1 / 256$ ) where $0.5 \mathrm{ml}$ of each dilution was inoculated $\mathrm{S} / \mathrm{C}$ in each of 5 Guinea pigs.

- The $2^{\text {nd }}$ group was vaccinated with FMD inactivated vaccine adjuvanted with ISA206 oil in the same manner in the first group.

- The $3^{\text {rd }}$ group was vaccinated with FMD inactivated vaccine adjuvanted vaccine ISA206 oil and carbomer in the same manner in the $1^{\text {st }}$ and $2^{\text {nd }}$ group.

- $\quad$ The $4^{\text {th }}$ group was kept without vaccination as a test control.

Three weeks later, all Guinea pigs in all groups were challenged with the specific Guinea pig adapted FMD virus (O, A, SAT2); by inoculation intradermoplanter. The challenged Guinea pigs were observed for 7 days to detect the infection generalization and the $\mathrm{GPPD}_{50}$ was calculated using the following formula:

The difference of logarithm $=$

Morbidity next above 50\% - 50\%

$\mathrm{X} \log$ of the dilution factor

Morbidity next above 50\% - Morbidity next below 50\%

The Guinea pigs were checked 4-5 days after applying the challenge test for the development of primary and secondary lesions. If the virus generalizes in the guinea pig's body, the vesicles on the uninoculated feet and the tongue are observed for a positive reaction to the FMDV infection. The observations were recorded and the 50\% Protective Dose $\left(\mathrm{PD}_{50}\right)$ was calculated in all groups and the control groups. 


\section{Effect of Carbomer as an Adjuvant for ........}

\subsubsection{Assessment of the humoral immune response}

This test includes $160 \mathrm{G}$. Pigs divided into 4groups (50 G. Pigs/ group in the first three groups and $10 \mathrm{G}$. Pigs in the $4^{\text {th }}$ group) as follow:

- Group (1) was vaccinated with the trivalent carbomer FMD vaccine

- Group (2) was vaccinated with the trivalent oil FMD

- Group (3) was vaccinated with the trivalent oilcarbomer FMD vaccine

- Group (4) was kept without vaccination as a control.
The used vaccine dose of each vaccine formula was $0.5 \mathrm{ml} / \mathrm{G}$. pig inoculated subcutaneously and serum samples were collected from the all-G. Pigs (vaccinated and nonvaccinated) to follow up the antibody titers against the serotypes of FMDV (A Iran O5, O Pan Asia2 and SAT 2/EGY/2012) through the application of serum neutralization test (SNT) using the microtiter technique as mentioned by Ferreira (1976) and indirect ELISA as described by Voller, et al., (1976) on week intervals up to 4 weeks then on two weeks interval up to 16 weeks then on four weeks intervals up to 36 weeks post-vaccination.

\section{RESULTS}

Table 1: FMD virus parameters

\begin{tabular}{|ccccc|}
\hline \multirow{2}{*}{ FMD virus types } & \multicolumn{5}{c|}{ Evaluated parameters } \\
\cline { 2 - 5 } & $\begin{array}{c}\text { Titer (log10 } \\
\text { TCID50/ml) }\end{array}$ & CFT Value & $\begin{array}{c}\text { Total protein } \\
(\mathrm{mg} / \mathrm{ml})\end{array}$ & $146 \mathrm{~S}(\mu \mathrm{g} / \mathrm{ml})$ \\
\hline O Pan Asia-2 & 8.5 & 64 & 3.8 & 3 \\
\hline An Iran O5 & 7.8 & 32 & 3.7 & 2.5 \\
\hline SAT-2/Egy. & 7.5 & 32 & 3.5 & 2.5 \\
2012 & & & \\
\hline
\end{tabular}

Table 2: GPPD50 of trivalent FMD with different vaccine formulae challenged with serotype (O):

\begin{tabular}{|c|c|c|c|c|c|c|c|c|c|c|c|c|c|c|c|c|c|c|}
\hline \multirow{2}{*}{$\begin{array}{l}\text { Vaccine } \\
\text { dilution }\end{array}$} & \multicolumn{3}{|c|}{ VG } & \multicolumn{3}{|c|}{ PG } & \multicolumn{3}{|c|}{ NPG } & \multicolumn{3}{|c|}{ CPG } & \multicolumn{3}{|c|}{ CNPG } & \multicolumn{3}{|c|}{ Protection $\%$} \\
\hline & $\Omega$ & $\frac{\Omega}{N}$ & 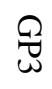 & $\Omega$ & 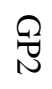 & $\overparen{\omega}$ & $\Omega$ & $\frac{2}{N}$ & $\Omega$ & $\Omega$ & $\frac{\Omega}{N}$ & 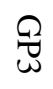 & $\Omega$ & $\stackrel{\Omega}{N}$ & $\Omega$ & $\Omega$ & $\Omega$ & $\Omega$ \\
\hline Undiluted & 5 & 5 & 5 & 5 & 5 & 5 & 0 & 0 & 0 & 16 & 18 & 21 & 0 & 0 & 0 & 100 & 100 & 100 \\
\hline $1 / 4$ & 5 & 5 & 5 & 5 & 5 & 5 & 0 & 0 & 0 & 11 & 13 & 16 & 0 & 0 & 0 & 100 & 100 & 100 \\
\hline $1 / 16$ & 5 & 5 & 5 & 4 & 4 & 5 & 1 & 1 & 0 & 6 & 8 & 11 & 1 & 1 & 0 & 85.7 & 88.8 & 100 \\
\hline $1 / 64$ & 5 & 5 & 5 & 2 & 3 & 4 & 3 & 2 & 1 & 2 & 4 & 6 & 4 & 3 & 1 & 33.3 & 57.1 & 85.7 \\
\hline $1 / 256$ & 5 & 5 & 5 & 0 & 1 & 2 & 5 & 4 & 3 & 0 & 1 & 2 & 9 & 7 & 4 & 0 & 12.5 & 33.3 \\
\hline
\end{tabular}

VG: No. of vaccinated guinea pigs, PG: No. of protected guinea pigs, NPG: No. of non-protected guinea pigs, CPG: Cumulative no. of protected guinea pigs, CNPG: Cumulative no. of non-protected guinea pigs, $($ GPPD50 of GP1 $)=40.6, \quad($ GPPD50 of Gp2 $)=78.6$ and $($ GPPD50 of GP3 $)=161.7$.

Table 3: GPPD50 of trivalent FMD with different vaccine formulae challenged with serotype (A):

\begin{tabular}{|c|c|c|c|c|c|c|c|c|c|c|c|c|c|c|c|c|c|c|}
\hline \multirow{2}{*}{$\begin{array}{l}\text { Vaccine } \\
\text { dilution }\end{array}$} & \multicolumn{3}{|c|}{ VG } & \multicolumn{3}{|c|}{ PG } & \multicolumn{3}{|c|}{ NPG } & \multicolumn{3}{|c|}{ CPG } & \multicolumn{4}{|c|}{ CNPG } & \multicolumn{2}{|c|}{$\begin{array}{c}\text { Protection } \\
\%\end{array}$} \\
\hline & $\Omega$ & त & 己ి & $\Omega$ & $\stackrel{\Omega}{N}$ & $\widetilde{\omega}$ & $\Omega$ & $\stackrel{\Omega}{N}$ & 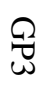 & $\Omega$ & $\frac{\pi}{N}$ & 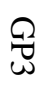 & $\Omega$ & $\frac{\pi}{N}$ & $\stackrel{\Omega}{\omega}$ & $\theta$ & $\frac{\Omega}{N}$ & 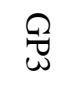 \\
\hline Undiluted & 5 & 5 & 5 & 5 & 5 & 5 & 0 & 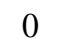 & 0 & 15 & 19 & 21 & 0 & 0 & 0 & 100 & 100 & 100 \\
\hline $1 / 4$ & 5 & 5 & 5 & 5 & 5 & 5 & 0 & 0 & 0 & 10 & 14 & 16 & 0 & 0 & 0 & 100 & 100 & 100 \\
\hline $1 / 16$ & 5 & 5 & 5 & 4 & 4 & 5 & 1 & 1 & 0 & 5 & 9 & 11 & 1 & 1 & 0 & 83.3 & 90 & 100 \\
\hline $1 / 64$ & 5 & 5 & 5 & 1 & 4 & 4 & 4 & 1 & 1 & 1 & 5 & 6 & 5 & 2 & 1 & 16.6 & 71.4 & 85.7 \\
\hline $1 / 256$ & 5 & 5 & 5 & 0 & 1 & 2 & 5 & 4 & 3 & 0 & 1 & 2 & 10 & 6 & 4 & 0 & 14.3 & 33.3 \\
\hline
\end{tabular}

VG: No. of vaccinated guinea pigs, PG: No. of protected guinea pigs, NPG: No. of non-protected guinea pigs, CPG: Cumulative no. of protected guinea pigs, CNPG: Cumulative no. of non-protected guinea pigs, $($ GPPD50 of GP1 $)=31.6,($ GPPD50 of GP2 $)=105.8$, and $($ GPPD50 of GP3 $)=161.7$. 


\section{Walaa S. Shabana and Abeer Abd EL-Sadek}

Table 4: GPPD50 of trivalent FMD with different vaccine formulae challenged with serotype (SAT2)

\begin{tabular}{|c|c|c|c|c|c|c|c|c|c|c|c|c|c|c|c|c|c|c|}
\hline \multirow[b]{2}{*}{$\begin{array}{l}\text { Vaccine } \\
\text { dilution }\end{array}$} & \multicolumn{3}{|c|}{ VG } & \multicolumn{3}{|c|}{ PG } & \multicolumn{3}{|c|}{ NPG } & \multicolumn{3}{|c|}{$\mathrm{CPG}$} & \multicolumn{3}{|c|}{ CNPG } & \multicolumn{3}{|c|}{ Protection $\%$} \\
\hline & $\Omega$ & $\stackrel{\Omega}{N}$ & $\widetilde{\omega}$ & $\Omega$ & $\Omega$ & 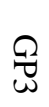 & $\Omega$ & $\Omega$ & $\Omega$ & $\Omega$ & $\stackrel{\Omega}{N}$ & 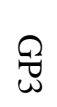 & $\Omega$ & $\Omega$ & $\widetilde{\omega}$ & $\Omega$ & N & తి \\
\hline Undiluted & 5 & 5 & 5 & 5 & 5 & 5 & 0 & 0 & 0 & 13 & 18 & 19 & 0 & 0 & 0 & 100 & 100 & 100 \\
\hline $1 / 4$ & 5 & 5 & 5 & 4 & 5 & 5 & 1 & 0 & 0 & 8 & 13 & 14 & 1 & 0 & 0 & 88.8 & 100 & 100 \\
\hline $1 / 16$ & 5 & 5 & 5 & 3 & 4 & 4 & 2 & 1 & 1 & 4 & 8 & 9 & 3 & 1 & 1 & 57.1 & 88.8 & 90 \\
\hline $1 / 64$ & 5 & 5 & 5 & 1 & 3 & 4 & 4 & 2 & 1 & 1 & 4 & 5 & 7 & 3 & 2 & 12.5 & 57.1 & 71.4 \\
\hline $1 / 256$ & 5 & 5 & 5 & 0 & 1 & 1 & 5 & 4 & 4 & 0 & 1 & 1 & 12 & 7 & 6 & 0 & 12.5 & 14.2 \\
\hline
\end{tabular}

VG: No. of vaccinated guinea pigs, PG: No. of protected guinea pigs, NPG: No. of non-protected guinea pigs, CPG: Cumulative no. of protected guinea pigs, CNPG: Cumulative no. of non-protected guinea pigs, $($ GPPD50 of GP1 $)=19.75,($ GPPD50 of GP2 $)=78.6$, and $($ GPPD50 of GP3 $)=105.8$.

Table 5: Mean FMD serum neutralizing index in G. Pigs vaccinated with different formulae of trivalent FMD vaccine

\begin{tabular}{|c|c|c|c|c|c|c|c|c|c|}
\hline \multirow{3}{*}{ WPV* } & \multicolumn{9}{|c|}{ Mean FMD serum NI in G. Pigs } \\
\hline & \multicolumn{3}{|c|}{$\mathrm{O}$} & \multicolumn{3}{|c|}{ A } & \multicolumn{3}{|c|}{ SAT } \\
\hline & GP 1 & GP 2 & GP 3 & GP 1 & GP 2 & GP 3 & GP 1 & GP 2 & GP 3 \\
\hline 0 & 0.6 & 0.3 & 0.3 & 0.15 & 0.6 & 0.15 & 0.45 & 0.3 & 0.45 \\
\hline 1 & 1.2 & 1.1 & 1.4 & 1.2 & 1.2 & 1.55 & 1.2 & 1.1 & 1.6 \\
\hline 2 & 1.5 & 1.3 & 1.6 & 1.65 & 1.7 & 1.9 & 1.35 & 1.5 & 1.8 \\
\hline 3 & 1.8 & 1.8 & 1.95 & 1.8 & 1.95 & 2.1 & 1.6 & 1.8 & 1.9 \\
\hline 4 & 2.1 & 2.2 & 2.4 & 2.1 & 2.2 & 2.4 & 1.85 & 1.9 & 2.3 \\
\hline 6 & 2.4 & 2.5 & 2.7 & 2.4 & 2.6 & 2.7 & 2.1 & 2.3 & 2.8 \\
\hline 8 & 2.7 & 2.8 & 2.9 & 2.7 & 2.85 & 3.0 & 2.4 & 2.6 & 3.05 \\
\hline 10 & 2.85 & 2.9 & 3.25 & 2.9 & 3.0 & 3.45 & 2.7 & 2.8 & 3.35 \\
\hline 12 & 2.7 & 3.1 & 3.25 & 2.85 & 3.1 & 3.25 & 2.55 & 3.05 & 3.25 \\
\hline 14 & 2.5 & 2.75 & 2.95 & 2.7 & 2.90 & 3.0 & 2.4 & 2.75 & 3.05 \\
\hline 16 & 2.4 & 2.7 & 2.85 & 2.55 & 2.70 & 2.9 & 2.1 & 2.55 & 2.95 \\
\hline 18 & 2.1 & 2.58 & 2.7 & 2.4 & 2.5 & 2.75 & 1.95 & 2.35 & 2.8 \\
\hline 20 & 1.8 & 2.38 & 2.55 & 2.25 & 2.4 & 2.6 & 1.8 & 2.15 & 2.65 \\
\hline 22 & 1.65 & 2.24 & 2.4 & 2.1 & 2.35 & 2.45 & 1.65 & 2.05 & 2.4 \\
\hline 24 & 1.5 & 2.05 & 2.3 & 1.8 & 2.15 & 2.4 & 1.5 & 1.95 & 2.25 \\
\hline 26 & 1.15 & 1.85 & 2.1 & 1.2 & 2.05 & 2.3 & 1.15 & 1.95 & 2.05 \\
\hline 28 & 0.9 & 1.77 & 1.95 & 1.05 & 1.85 & 2.1 & 1 & 1.8 & 1.95 \\
\hline 30 & 0.9 & 1.70 & 1.95 & 0.9 & 1.7 & 1.95 & 0.45 & 1.8 & 1.8 \\
\hline 32 & 0.45 & 1.67 & 1.8 & 0.3 & 1.5 & 1.95 & 0.3 & 1.65 & 1.7 \\
\hline 34 & 0.3 & 1.54 & 1.65 & 0.3 & 1.1 & 1.8 & 0.3 & 1.5 & 1.65 \\
\hline 36 & 0.3 & 1.12 & 1.5 & 0 & 0.9 & 1.5 & 0.3 & 1.15 & 1.5 \\
\hline 38 & 0 & 0.9 & 1.15 & 0 & 0.45 & 1.05 & 0 & 0.9 & 1.1 \\
\hline
\end{tabular}

$* \mathrm{WPV}=$ week post vaccination

$\mathrm{PT}$ by $\mathrm{SNT}=1.2$ 
Table 6: Mean FMD ELISA antibody titters in G. Pigs vaccinated with different formulae of trivalent FMD vaccine

\begin{tabular}{|c|c|c|c|c|c|c|c|c|c|}
\hline \multirow{3}{*}{ WPV* } & \multicolumn{9}{|c|}{ Mean FMD ELISA antibody titer $(\log 10)$ in G. Pigs } \\
\hline & \multicolumn{3}{|c|}{$\mathrm{O}$} & \multicolumn{3}{|c|}{ A } & \multicolumn{3}{|c|}{ SAT } \\
\hline & GP 1 & GP 2 & GP 3 & GP 1 & GP 2 & GP 3 & GP 1 & GP 2 & GP 3 \\
\hline 0 & 0.8 & 0.5 & 0.5 & 0.4 & 0.85 & 0.4 & 0.68 & 0.53 & 0.68 \\
\hline 1 & 1.4 & 1.3 & 1.6 & 1.45 & 1.45 & 1.8 & 1.43 & 1.33 & 1.83 \\
\hline 2 & 1.7 & 1.5 & 1.8 & 1.9 & 1.95 & 2.15 & 1.58 & 1.73 & 2.03 \\
\hline 3 & 2 & 2 & 2.15 & 2.05 & 2.2 & 2.35 & 1.83 & 2.03 & 2.13 \\
\hline 4 & 2.3 & 2.4 & 2.6 & 2.35 & 2.45 & 2.65 & 2.08 & 2.13 & 2.53 \\
\hline 6 & 2.6 & 2.7 & 2.9 & 2.65 & 2.85 & 2.95 & 2.33 & 2.53 & 3.03 \\
\hline 8 & 2.9 & 3 & 3.1 & 2.95 & 3.1 & 3.25 & 2.63 & 2.83 & 3.28 \\
\hline 10 & 3.05 & 3.1 & 3.45 & 3.15 & 3.25 & 3.7 & 2.93 & 3.03 & 3.58 \\
\hline 12 & 2.9 & 3.3 & 3.45 & 3.1 & 3.35 & 3.5 & 2.78 & 3.28 & 3.48 \\
\hline 14 & 2.7 & 2.95 & 3.15 & 2.95 & 3.15 & 3.25 & 2.63 & 2.98 & 3.28 \\
\hline 16 & 2.6 & 2.9 & 3.05 & 2.8 & 2.95 & 3.15 & 2.33 & 2.78 & 3.18 \\
\hline 18 & 2.3 & 2.78 & 2.9 & 2.65 & 2.75 & 3 & 2.18 & 2.58 & 3.03 \\
\hline 20 & 2 & 2.58 & 2.75 & 2.5 & 2.65 & 2.85 & 2.03 & 2.38 & 2.88 \\
\hline 22 & 1.85 & 2.44 & 2.6 & 2.35 & 2.6 & 2.7 & 1.88 & 2.28 & 2.63 \\
\hline 24 & 1.7 & 2.25 & 2.5 & 2.05 & 2.4 & 2.65 & 1.73 & 2.18 & 2.48 \\
\hline 26 & 1.35 & 2.05 & 2.3 & 1.45 & 2.3 & 2.55 & 1.38 & 2.18 & 2.28 \\
\hline 28 & 1.1 & 1.97 & 2.15 & 1.3 & 2.1 & 2.35 & 1.23 & 2.03 & 2.18 \\
\hline 30 & 1.1 & 1.9 & 2.15 & 1.15 & 1.95 & 2.2 & 0.68 & 2.03 & 2.03 \\
\hline 32 & 0.65 & 1.87 & 2 & 0.55 & 1.75 & 2.2 & 0.53 & 1.88 & 1.93 \\
\hline 34 & 0.5 & 1.74 & 1.85 & 0.55 & 1.35 & 2.05 & 0.53 & 1.73 & 1.88 \\
\hline 36 & 0.5 & 1.32 & 1.7 & 0.25 & 1.15 & 1.75 & 0.53 & 1.38 & 1.73 \\
\hline 38 & 0.2 & 1.1 & 1.35 & 0.25 & 0.7 & 1.3 & 0.23 & 1.13 & 1.33 \\
\hline
\end{tabular}

*WPV= week post-vaccination

Group (1) vaccinated with the trivalent carbomer FMD vaccine.

Group (2) vaccinated with the trivalent oil FMD

Group (3) vaccinated with the trivalent oil-carbomer FMD vaccine

\section{DISCUSSION}

All of the prepared inactivated polyvalent FMD vaccines showed homogenous appearance; free from aerobic and anaerobic bacteria; fungi and mycoplasma were tested on specific media and safe inducing no abnormalities in inoculated G. pigs. There was no noticeable toxicity or prolonged pyrexia was observed in the vaccinated G. Pigs, in agreement with the recommendation of (Stone,1988) and (OIE 2017).

FMD still represents a non-neglectable problem in livestock in many countries, resulting in huge economic losses, especially in developing countries. Regarding Egypt, several outbreaks attack the country due to the infection with either type O, A, SAT2 (Aidaros, 2002). Monovalent
FMD vaccine type $\mathrm{O}$ was used for several years where it was the only recorded type in Egypt (Parida Satya, 2009) after that and according to the introduction of type A, a bivalent vaccine was successfully prepared to contain both type $\mathrm{O}$ and $\mathrm{A}$ (Knowles et al., 2007; Assem, 2010; Gamil, 2010; El-Sayed, 2011 and 2012). More recently, FMDV type SAT2 was recorded in Egypt (Ahmed $\boldsymbol{e t}$ al., 2012 and Shawky et al., 2013) and this required the preparation of a trivalent vaccine containing the three present serotypes (A, O, SAT2). The present study was planned as preliminary work to establish such vaccine formulae by determining the best formulae that induce the highest $\mathrm{GPPD}_{50}$.

The obtained results revealed that the virus titers of the FMDV serotypes (O Pan Asia-2, A Iran O5 and SAT/EGY/2012) were 8.5, 7.8 and 7.5 
$\log 10 \mathrm{TCID}_{50} / \mathrm{ml}$ with CFT value of 64,32 and 32 total protein and 146S antigen contents 3.8, 3.7 and $3.5 \mathrm{mg} / \mathrm{ml}$ for the three serotypes respectively as tabulated in the table (1).

Determination of $\mathrm{GPPD}_{50}$ induced by the prepared trivalent FMD vaccine formulae revealed that the values of 40.6; 78.6 and 161.7 against serotype $O$ in G. group-1 which vaccinated with FMD carbomer adjuvanted vaccine; group-2 which vaccinated with FMD Montanide ISA 206 oil adjuvanted vaccine and group-3 which vaccinated with FMD Montanide ISA 206 oil carbomer adjuvanted vaccine respectively. It was found that the $\mathrm{GPPD}_{50}$ against serotype A 31.6; 105.8 and 161.7 in group-1; 2 and 3 which vaccinated with FMD carbomer adjuvanted vaccine the; Montanide ISA 206 oil adjuvanted vaccine and Montanide ISA 206 oil carbomer adjuvanted vaccine respectively. The three G. pig groups showed GPPD $_{50}$ values of $19.75 ; 78.6$ and 105.8 against serotype SAT2, respectively.

These results are tabulated in tables $(2,3,4)$, coming in agreement with Pay and Hingley (1987), who used the same FMD vaccine virus concluding that $2.2 \mu \mathrm{g}$ of the antigen was required to obtain 1 PD50. However, protection was observed even with lower antigen dose but disagree with Morgan et al., (1969) who mentioned that many trials had been conducted to correlate the quantity of $146 \mathrm{~S}$ virus particles per vaccine dose and the protection and immunity achieved. The minimum effective dose of purified FMDV A-119 required for eliciting a virus-neutralizing immune response in guinea pigs was about $1.6 \mu \mathrm{g}$; this disagreement could be attributed to the different used subtypes of FMDV type A.

Testing of G. pig's serum samples of vaccinated animals with carbomer alone; to confirm the results of $\mathrm{GPPD}_{50}$ using SNT; showed neutralizing antibody titer of 1.2, 1.2 and $1.2 \log _{10} / \mathrm{ml}$ against FMDV serotype $\mathrm{O}$ Pan Asia-2; A Iran O5 and SAT/EGY/2012 respectively at $1^{\text {st }}$ WPV with peak antibody titers at $10^{\text {th }}$ WPV $(2.85,2.9$ and 2.7 respectively and extended till $24^{\text {th }}$ to $25^{\text {th }}$ WPV $1.5,1.2,1.5$ in the three groups respectively. G. pig's serum samples from animals vaccinated with Montanide ISA206 alone showed antibody titer 1.3, 1.2 and 1.5 against FMDV serotype O Pan Asia-2, A Iran O5 and SAT/EGY/2012, respectively at $2^{\text {nd }}$ or $3^{\text {rd }}$ WPV with peak antibody titer at $12^{\text {th }}$ WPV $(3.1,3.1$ and 3.05$)$ respectively and extended till the $32^{\text {nd }}$ to $34^{\text {th }}$ WPV $(1.54,1.5,1.5)$ respectively.

On the other side G. pig vaccinated with Montanide ISA206 with carbomer showed antibody titer of 1.4, 1.55 and 1.6 against FMDV serotype O Pan
Asia-2, A Iran O5 and SAT/EGY/2012 respectively at the $1^{\text {st }}$ WPV with peak antibody titer at $10^{\text {th }}$ WPV $(3.25,3.45$ and 3.35$)$ and extended till the $36^{\text {th }}$ WPV $(1.5,1.5,1.5)$ respectively.

Testing of G. pig's serum samples of vaccinated animals with carbomer alone; to confirm the results of GPPD $_{50}$ using ELISA; showed antibody titer of 1.7, 1.9 and $1.58 \log _{10} / \mathrm{ml}$ against FMDV serotype O Pan Asia2; A Iran O5 and SAT/EGY/2012 respectively at $2^{\text {nd }}$ WPV with peak antibody titers at $10^{\text {th }}$ WPV $(3.05,3.15$ and 2.93 respectively and extended till $24^{\text {th }}$ WPV 1.7 , $2.05,1.73$ in the three groups respectively. G. pig's serum samples from animals vaccinated with Montanide ISA206 alone showed antibody titer 1.5, 1.95 and 1.73 against FMDV serotype O Pan Asia-2, A Iran 05 and SAT/EGY/2012 respectively at $2^{\text {nd }}$ WPV with peak antibody titer at $12^{\text {th }}$ WPV $(3.3,3.35$ and $3.28)$ respectively and extended till the $32^{\text {nd }}$ to $34^{\text {th }}$ WPV $(1.74,1.75,1.73)$ respectively. On the other side G. pig vaccinated with Montanide ISA206 with carbomer showed antibody titer of 1.6, 1.8 and 1.83 against FMDV serotype O Pan Asia-2, A Iran O5 and SAT/EGY/2012 respectively at the $1^{\text {st }}$ WPV with peak antibody titer at $10^{\text {th }}$ WPV $(3.45,3.7$ and 3.58$)$ and extended till the $36^{\text {th }}$ WPV $(1.7,1.75,1.73)$ respectively.

Such titers appear to be higher than the recommended protective antibody titer indicating that the prepared trivalent FMD vaccine able to induce acceptable immune level in vaccinated G. pigs where the obtained antibody titer against the three serotypes was found to be higher than the recommended protective antibody titer $(\mathrm{PT}=1.2)$ coming in a parallel manner with that of GPPD 50 . These finding coming in agreement with those of Motamedi et al., (2007) who found that after the vaccines were inoculated subcutaneously on the back foot in two groups of guinea pigs, just two of ten animals showed antiserum titration above the protective titration $(\mathrm{PT}=1.2)$, and the other eight animals were below the PT.

\section{CONCLUSION}

Finally, it could be concluded that G. pigs can be used as an animal model for FMD vaccine evaluation instead of cattle to low the required cost and efforts. Also, it could be concluded that the FMD vaccine adjuvanted with carbomer alone give early immunity than the oil vaccine alone but the combination between carbomer and Montanide ISA206 oil induces early immunity with high antibody levels extends longer than that induced by other adjuvants and further studies are required in cattle to confirm the results. 


\section{Declaration of Competing interest}

On behalf of all authors, I hereby declare that no conflict of interest may interfere with the publication of the manuscript.

\section{REFERENCES}

ABD EL-ATY, SM, FAKRY, HM, HIND, MD, ELSAYED, EI, WAEL MG, RIZK, SA, ABUELNAGA, H., MOHAMED, AA, ABD ELKREEM, A. AND FAROUK EM 2013. Isolation and Molecular characterization of foot and mouth disease sat2 virus during outbreak 2012 in Egypt. J. Vet. Adv., 3(2): 60-68.

ABD EL-RAHMAN, A. O., FARAG, M. A., SAMIRA EL- KILANY, EMAN, M. A., MANAL ABO EL YAZED AND ZEIDAN, S. 2006. Isolation and identification of FMDV during an outbreak of 2006 in Egypt. Kafr El- Sheikh Vet. Med. J.; 4(1).

AHMED HA, SALEM SA, HABASHI AR, ARAFA AA, AGGOUR MG, SALEM GH, GABER AS, SELEM O, ABDELKADER SH, KNOWLES NJ, MADI M, VALDAZO-GONZÁLEZ B, WADSWORTH J, HUTCHINGS GH, MIOULET V, HAMMOND JM, KING DP 2012. Emergence of foot-and-mouth disease virus SAT 2 in Egypt during 2012. Transbound Emerg Dis. 2012 Dec;59(6):476-81. doi: 10.1111/tbed.12015.

AIDAROS, HA 2002 Regional status and approaches to control and eradication of FMD in the middle east and North Africa. Rev. Sci. Tech. Off. Int. Epizoot., 21(3): 451-458.

ALKAN M., S. GURCAN, M. F. SARAC, Y. GULTEKIN, A. ARSLAN, E. UZUNLU, S. AKYUZ AND G. AYNAGOZ 2008. Development of a Foot and Mouth disease vaccine potency tests without conducting animal challenge experiment. The Global control of FMD - Tools, ideas and ideals Erice, Italy 14-17 October 2008, pp.181-186

ASSEM ABU BAKR MOHAMED 2010. Trial for preparation of bivalent oil adjuvant FMD vaccine. $\mathrm{Ph}$. D Faculty of Veterinary Medicine, Department of Microbiology Alexandria University.

BARTELING SJ AND CASSIM NI 2004. Very fast (and safe) inactivation of foot-and-mouth disease virus and enteroviruses by a combination of binary ethyleneimine and formaldehyde. Dev Biol (Basel).,119: 449-55.

BARTELLING, A. S. J., VAN MAANAN, C., YADIN, H. AND ANEMAET, D. A. J. 1990. A Foot and Mouth Disease vaccine bank; purified inactivated antigen stored at ultra-low temperatures for the rapid preparation of double oil emulsion vaccines. European commission for control of Foot and Mouth Disease. Session of Research Group of the standing technical Committee, Lindholm, 172-177.

BLACK; FRANCIS, MJ; RWEYEMAMU, MM; UMEHARA, O. AND BOGE, A. 1985. The relationship between serum antibody titers and protection from foot and mouth disease in pigs after oil emulsion vaccination. J.Biol.Stand., 12(4): 379389.
CHALlA, S., SZCZEPANEK, S.M., ROOD , D. BARRETTE, R.W., SILBART, L.K., 2011 Bacterial Toxin Fusion Proteins Elicit Mucosal Immunity against a Foot-and-Mouth Disease Virus Antigen When Administered Intranasally to Guinea Pigs. Advances in Virology 2011:713769. Epub 2011 Sep 22.

DEPA, P.M., DIMRI, U., SHARMA, MC, AND TIWARI, R. 2012. Update on epidemiology and control of foot and mouth disease - A menace to international trade and global animal enterprise. Vet. World, 5(11): 694-704.

DEY AK, BURKE B, SUN Y, HARTOG K, HEENEY JL, MONTEFIORI D. 2012. Use of a polyanionic carbomer, Carbomere971P, in combination with MF59, improves antibody responses to HIV-1 envelope glycoprotein. Vaccine; 30:2749-59.

DOEL TR 2003 FMD vaccines. Virus Res 91: 81-99.

DOEL, TR, CHONG, WKT, 1982. Comparative immunogenicity of $146 \mathrm{~s}, 75 \mathrm{~s}$, and $12 \mathrm{~s}$ particles of FMDV. Arch. Virol. 73, 185/191.

EL-SAYED, EIM, 2011. Advanced studies on Foot and Mouth Disease Vaccines of sheep in Egypt. Ph D.Sc. Thesis (Infectious Diseases), Faculty of Veterinary Medicine, Cairo University, Egypt.

EL-SAYED, E I AND SALMA A SHOULAH. 2021 "Effect of Carbopol as an Immune-Stimulant in Bovine Vaccination against Foot and Mouth Disease." EC Veterinary Science 6.1: 37-47.

EL-SAYED E, WAEL MOSSAD GAMAL EL-DIN, SONIA AHMED RIZK AND MAGDI ABD ELATY 2012. Effect of Different Storage Temperatures on the Efficacy of the Bivalent Foot and Mouth Disease Oil Vaccine. Journal of Advanced Veterinary Research Volume 2, pp.198-205

EMAN M, EL- GARF 2012 Using of guinea Pigs as animal model to determine the PD50 of local oil bivalent FMD vaccine. 7th Int. Sci. Conf., Mansoura 28-30 August. Pp. 797-809.

FERREIRA, MEV 1976. Microtiter neutralization test for the study of FMD antibodies. Bol. Centro Pan Americano de Fiebre Aftosa, 21: 22-23.

GAMIL MA 2010. Studies on the immune response of calves vaccinated inactivated bivalent FMD virus vaccine type $\mathrm{O} 1$ and A Egypt 2006. M. V. Sc in Veterinary Science (virology). Benha University

GARTLAN KATE H., GEORGE KRASHIAS, FRANK WEGMANNA, WILLIAM R. HILLSONA, ERIN M. SCHERER, PHILIP D. GREENBERG, STEPHANIE C. EISENBARTH, AMIN E. MOGHADDAMA, QUENTIN J. SATTENTAUA 2016. Sterile inflammation induced by Carbomere elicits robust adaptive immune responses in the absence of pathogen-associated molecular patterns. Vaccine, http://dx.doi.org/10.1016/j.vaccine. 03.025

GRUBMAN MJ, BAXT B 2004 Foot-and-mouth disease. Clin Microbiol Rev 17:465-493

GUALANDI GL, LOSIO NM, MURATORI G, FONI E. 1988. The ability by different preparations of porcine parvovirus to enhance humoral immunity in swine and guinea pigs. Microbiologica; 11:363-9.

HEALTH PROTECTION AGENCY 2009. Complement fixation tests. Issue no:3 Issue date 11.12.09 Issued 
by standards unit, Department for Evaluations, standards and Training page 1 of 23.

HOOGLAND MJ, OPRIESSNIG T, HALBUR PG. 2006. Effects of adjuvants on porcine circovirus type 2associated lesions. J Swine Health Prod; 14:133-9.

ISMAIL, A.H., EL-MAHDY, S.A., MOSSAD, WG, ABD EL-KRIM, AS, ABOU EL-YAZID, M. AND ALI, S.M 2013. Optimization of the inactivation process of FMD virus serotype SAT-2 by binary ethyleneimine (BEI). J. Vet, Adv., 3(3): 117-124.

JACQUELINE GELFI, MICHAEL PAPPALARDO, CARINE CLAVERYS, BRIGITTE PERALTA, JEAN-LUC GUERIN 2011. Safety and efficacy of an inactivated Carbomere-adjuvanted Goose haemorrhagic polyomavirus vaccine for domestic geese. Avian Pathology, Taylor \& Francis, 39 (02), pp.111-116.

KNOWLES NICK J., JEMMA WADSWORTH, SCOTT M. REID, KATHERINE G. SWABEY, ALAA A. EL-KHOLY, ADEL OMAR ABD EL-RAHMAN, HATEM M. SOLIMAN, KATJA EBERT, NIGEL P. FERRIS, GEOFFREY H. HUTCHINGS, ROBERT J. STATHAM, DONALD P. KING, AND DAVID J. PATON 2007. Foot-and-Mouth Disease Virus Serotype A in Egypt. Emerg Infect Dis. 2007 October; 13(10): 1593-1596. doi: 10.3201/eid1310.070252

KRASHIAS G, SIMON AK, WEGMANN F, KOK WL, HO LP, STEVENS D. 2010 Potent adaptive immune responses induced against HIV-1 gp140 and influenza virus $H A$ by a polyanionic carbomer. Vaccine; 28:2482-9.

LAI RP, SEAMAN MS, TONKS P, WEGMANN F, SEILLY DJ, FROST SD. 2012. Mixed adjuvant formulations reveal a new combination that elicits antibody response comparable to Freund's adjuvants. PLOS ONE; 7:e35083.

LIU IK, TURNER JR JW, VAN LEEUWEN EM, FLANAGAN DR, HEDRICK JL, MURATA K. 2005. Persistence of anti-zonae pellucidae antibodies following a single inoculation of porcine zonae pellucidae in the domestic equine. Reproduction; 129:181-90.

MAIR KH, KOINIG H, GERNER W, HOHNE A, BRETTHAUER J, KROLL JJ. 2015. Carbomer improves the early cellular immune responses induced by the modified-life vaccine Ingelvac PRRS((R)) MLV. Vet Microbiol; 176:352-7.

MINKE, JM, TOULEMONDE, CE, DINIC, S., COZETTE, V., CULlinANE, A. \& AUDONNET, J. C. 2007. Effective priming of foals born to immune dams against influenza by a canarypox-vectored recombinant influenza $\mathrm{H} 3 \mathrm{~N} 8$ vaccine. Journal of Comparative Pathology, 137, Supplement 1: S76-80.

MORGAN DO, BACHRACH HL, MCKERCHER PD. 1969. Immunogenicity of nanogram to milligram quantities of inactivated foot-and-mouth disease virus. Part I. Relative virus-neutralizing potency in guinea pig sera. Appl Microbiol; 17(3): 441-5.

MOTAMEDI SEDEH F., A. KHORASANI, K. SHAFAEE, M. SALEHIZADEH, H. FATOLAHI, K. ARBABI, S. DANESHVARI AND M. ABHARI 2007. immune response of foot and mouth disease virus type a87/irn inactivated vaccine by gamma irradiation on Guinea pig in Iran, Iranian Journal of Science \& Technology, Transaction A, Vol. 31, No. A1

MUMFORD JA, WILSON H, HANNANT D, JESSETT DM. 1994. Antigenicity and immunogenicity of equine influenza vaccines containing a Carbomer adjuvant. Epidemiol Infect; 112:421-37.

NAGLAA I. ALY, OMAIMA A. EL-SHAMANDY, SHENDY, MB; FATMA F. WARDA; AND EKBAL, M. FAROUK 2020. Efficacy of using carbomer as an adjuvant for Tissue Culture Inactivated Rabies Vaccine. Journal of Applied Veterinary Sciences, 5(3): 103-107

OIE 2017. FMD, Chapter 2.1.5. In manual of Standard for Diagnostic Test and Vaccine, Paris, pp.77-92.

PARIDA SATYA 2009. Vaccination against foot-and-mouth disease virus: strategies and effectiveness Expert Rev. Vaccines 8(3), 347-365

PAY TWF, HINGLEY PJ. 1987. Correlation of $140 \mathrm{~S}$ antigen dose, the serum-neutralizing antibody response and the level of protection induced in cattle by foot-and-mouth disease vaccines. Vaccine 1987; 5:60-4.

REED, L.J. AND MUENCH, H. 1938. A simple method for estimating fifty percent $(50 \%)$ endpoints. Am. J. Hyg., 27: 493-497.

RICHARD C. KNUDSEN, CHRISTOPHER M. GROOCOCK, AND ARTHUR A. ANDERSEN 1979. Immunity to Foot-and-Mouth Disease Virus in Guinea Pigs: Clinical and Immune Responses. Infection And Immunity, June 1979, p. 787-792 Vol. 24 , No. 3

SAMIRA EL-KILANY, EL- WATANY, H., ABD ELRAHMAN, A.O., FADIA FAHMY, 1999. The effect of long-term storage at $4^{\circ} \mathrm{C}$ on the stability of FMD vaccine formulated with different adjuvants. Alexandria Journal of Veterinary Sciences 15 (1), 3542.

SATYA, P. 2009. Vaccination against foot-and-mouth disease virus: Strategies and effectiveness. Expert Rev. Vaccines, 8(3): 347-365.

SHAWKY M., ABD EL-ATY M., HIAM. M. FAKRY, HIND M. DAOUD, EHAB EL-SAYED I., WAEL MOSSAD G., SONIA A. RIZK, ABU-ELNAGA H., MOHAMED A. A., ABD EL-KREEM A. AND FAROUK E. M. 2013. Isolation and Molecular Characterization of Foot and Mouth Disease SAT2 Virus during Outbreak 2012 in Egypt. J Vet Adv 2013, 3(2): 60-68. DOI: 10.5455/jva.20130219104353

SHIARI J., CHATCHAWANCHONTEERA A., SINSUWONGWAT W., MAKARASEN P. AND SUGIMURA T. 1990. Estimation of $140 \mathrm{~S}$ particles in FMD virus vaccine by using the computer analyzing system. Jap. J. Vet. Sci., 52(3): 621 - 630.

SONIA RIZK 2007. Studies on the preparation of an improved Foot and Mouth Disease oil vaccine. $\mathrm{Ph}$. D. Thesis, University of Cairo

STONE, HD 1988. Optimization of hydrophile-lipophile balance for improved efficacy of ND and avian influenza oil emulsion vaccines. Avian Disease, 32: 68-73. 
TOLLERSRUD T, NORSTEBO PE, ENGVIK JP, ANDERSEN SR, REITAN LJ, LUND A. 2002. Antibody responses in sheep vaccinated against Staphylococcus aureus mastitis: a comparison of two experimental vaccines containing different adjuvants. Vet Res Communication; 26:587-600.

VEREECKEN M., DE HERDT P., DUCATELLE R. AND HAESEBROUCK, F. 2000 The effect of vaccination on the course of an experimental Salmonella Typhimurium infection in racing pigeons. Avian Pathology, 29, 465- 471.

VOLLER, A., BID WELL, D. AND BARTLEHA 1976. Microplate enzyme immunoassay for the immunodiagnosis of virus infection. Am. Soc. For Micro. (506-512).

XUAN H., LI Y., FANG, H. AND ZHENG, C. 2011. Establishment of persistent infection with foot and mouth disease virus in BHK-21 cells. Virol. J., 8: 169.

How to cite this article:

Walaa S. Shabana and Abeer Abd EL-Sadek, 2021. Effect of Carbomer as an Adjuvant for Enhancement of Immune-Response Against FMD Vaccine. Journal of Applied Veterinary Sciences, 6 (2): $27-36$.

DOI: https://dx.doi.org/10.21608/javs.2021.154578 